\title{
Study the Nature and the Effects of the Impurities of Phosphate Rock in the Plants of Production of Phosphoric Acid
}

\author{
Ahmed CHAABOUNI ${ }^{\mathrm{a}}$, Chaker $\mathrm{CHTARA}^{\mathrm{b}}$, Ange NZIHOU ${ }^{\mathrm{C}}$, Hafed EL FEKI ${ }^{\mathrm{d} *}$ \\ a'Laboratory of sciences of materials and environment, Faculty of Sciences of Sfax, Sfax, Tunisia. \\ Soukra Road km 4 - B.P. n 802 - 3038 Sfax \\ E-mail:ahmed_chfss@yahoo.fr \\ ${ }^{\mathrm{b}}$ Tunisian Chemical group, Gabes, Tunisia. \\ Tunisian Chemical Group Research Directorate Z.I. BP72 - 6000 - GABES \\ E-mail:chaker.chtara@gmail.fr \\ ${ }^{\mathrm{C} E n g i n e e r i n g ~ S c h o o l ~ o f ~ M i n e s ~ o f ~ A l b i-C a r m a u x, ~ T o u l o u s e, ~ F r a n c e . ~}$ \\ Engineering School of Mines of Albi-Carmaux RAPSODEE Centre Campus Jarlard 81013 Albi CT Cedex 09 \\ E-mail:ange.nzihou@mines-albi.fr \\ dLaboratory of sciences of materials and environment, Faculty of Sciences of Sfax, Sfax, Tunisia. \\ Soukra Road km 4 - B.P. n 802 - 3038 Sfax \\ E-mail: hafed.elfeki@yahoo.fr \\ ${ }^{*}$ Corresponding author: E-mail address: hafed.elfeki@yahoo.fr
}

\begin{abstract}
Phosphate rocks from different deposits vary widely in composition, and these variations have important effects in phosphoric acid production. All phosphate rocks contain many impurities. Knowledge of the nature and contents of the various elements in the phosphate is required in the manufacturing process of phosphoric acid. All these chemical characteristics can help the operator to foresee its objectives under the operating conditions and the cost of production in the manufacturing process of phosphoric acid.

Two Tunisian natural phosphates coming from two different deposits were selected. We propose in this work studying the effects of the impurities that depending on their concentration can affect decisively the behavior of these ores in the process of production of phosphoric acid. Study the chemical composition of these ores is carried out according to standard analytical methods used for raw phosphates.

The results obtained show a slight difference in chemical properties between the two types of sedimentary phosphates and their aptitude to be used in the plants of production of phosphoric acid.
\end{abstract}

\section{Indexing terms/Keywords}

Natural phosphate; Chemical characterizations; Effect of the impurities; Process for producing phosphoric acid.

\section{Academic Discipline And Sub-Disciplines}

Geochemistry

\section{SUBJECT CLASSIFICATION}

Analytical chemistry

\section{TYPE (METHOD/APPROACH)}

Chemical Engineering

\section{Council for Innovative Research}

Peer Review Research Publishing System

Journal: Journal of Advances in Chemistry

Vol. 7, No. 2

editor@cirworld.com

www.cirworld.com, member.cirworld.com 


\section{INTRODUCTION}

Phosphates exist most commonly in the earth's crust. Phosphorus averages $1180 \mathrm{ppm}$. The most easily mined phosphate deposits are found in the great sedimentary basins [1]. Phosphates ore are intercalated with sedimentary stratus of other waste materials or similar ores interpenetrated by gangue minerals [1].

Wet process phosphoric acid technology comprises essentially the sulfuric acid attack and the separation ofthe phosphoric acid produced from the calcium sulfate crystals resulting from the reaction. Both the attack and the separation, which is effected by filtration, are considerably affected by the nature of the ore and its impurities. Besides calcium phosphate, the phosphate ores contain 10-15 major impurities and another 16 or so trace elements. Organic matter, also present in many ores, is not included in this estimation. Each element contained in the ore has its individual transfer coefficient into product acid and waste solids. Phosphoric acid is a major component of many fertilizers. It is mainly produced by digestion of phosphate ore (fluoroapatite) with sulfuric acid. This yields phosphoric acid as a product and hydrated calcium sulphate as a by-product. The ore also contains traces of heavy metal ions, as cadmium and radium are the most worrisome. They can cause serious environmental problems [2].

If phosphate ore is digested by phosphoric acid, the following reactions can take place [3]:

$$
\begin{aligned}
& \mathrm{Ca}_{10}\left(\mathrm{PO}_{4}\right)_{6} \mathrm{~F}_{2}+4 \mathrm{H}_{3} \mathrm{PO}_{4} \rightarrow 10 \mathrm{CaHPO}_{4}+2 \mathrm{HF} \\
& \mathrm{Ca}_{10}\left(\mathrm{PO}_{4}\right)_{6} \mathrm{~F}_{2}+14 \mathrm{H}_{3} \mathrm{PO}_{4} \rightarrow \quad 10 \mathrm{Ca}\left(\mathrm{H}_{2} \mathrm{PO}_{4}\right)_{2}+2 \mathrm{HF}
\end{aligned}
$$

When a mixture of phosphoric acid and sulfuric acid is used for the digestion of the ore, two processes occur more or less simultaneously: digestion of the ore and precipitation of calcium sulfate. Several reactions take place simultaneously and the effective rates of these reactions are very sensitive to the solution composition, agitation, temperature, and rock characteristics. The reaction between phosphate rocks and acids is essentially a surface reaction [4].

According to the phosphate composition, we propose in this work studying the effects of the impurities depending on their contents, they have a decisive effect in the plants of production of phosphoric acid.

\section{EXPERIMENTAL}

\subsection{Atomic absorption}

This technique is used to evaluate the free atoms concentration at a temperature of $2000^{\circ} \mathrm{C}$. Thus we have a total quantification of each analyzed element. The apparatus used to determine the atomic absorption of phosphates is PerkinElmer AA 200.

\subsection{Flame spectrophotometry}

It is based on measuring the power radiated by the fraction of thermally excited atoms for a given wavelength. In practice, we take measurements of the standards and the unknown solution at the same time in order to be exactly under the same conditions. This method is particularly sensitive for the alkalis. The apparatus used is a type of « RENDHOF ».

\section{RESULTS AND DISCUSSION}

The principal reaction occurring in a phosphoric acid plant is the reaction between phosphate rock and sulfuric acid to give soluble phosphoric acid and insoluble calcium sulfate. However, phosphate rocks contain many impurities that have important effects in phosphoric acid production. The chemical composition is done according to standard analytical methods used for phosphates and whose results given in weight percentages appear in the following table 1.

Table 1. Chemical Analysis of the Samples of phosphate.

\begin{tabular}{|c|c|c|}
\hline Phosphate & 1 & 2 \\
\hline$\% \mathrm{P}_{2} \mathrm{O}_{5}$ & 30.79 & 30.66 \\
\hline$\% \mathrm{CaO}$ & 49.75 & 49.63 \\
\hline$\% \mathrm{H}_{2} \mathrm{O}$ & 1.00 & 1.40 \\
\hline$\% \mathrm{CO}_{2}$ & 6.56 & 6.47 \\
\hline$\% \mathrm{C}_{\text {org }}$ & 0.22 & 0.24 \\
\hline$\% \mathrm{SO}_{3}$ & 3.34 & 3.39 \\
\hline $\mathrm{Cd}(\mathrm{ppm})$ & 10 & 11 \\
\hline$\% \mathrm{Na}_{2} \mathrm{O}$ & 1.45 & 1.42 \\
\hline$\% \mathrm{~K}_{2} \mathrm{O}$ & 0.04 & 0.04 \\
\hline $\mathrm{Cl}(\mathrm{ppm})$ & 947 & 918 \\
\hline
\end{tabular}




\begin{tabular}{|c|c|c|}
\hline$\% \mathrm{~F}$ & 3.14 & 3.21 \\
\hline$\% \mathrm{MgO}$ & 0.62 & 0.69 \\
\hline$\% \mathrm{SiO}_{2}$ & 3.96 & 2.51 \\
\hline$\% \mathrm{Al}_{2} \mathrm{O}_{3}$ & 0.43 & 0.46 \\
\hline$\% \mathrm{Fe}_{2} \mathrm{O}_{3}$ & 0.18 & 0.19 \\
\hline
\end{tabular}

$\mathrm{CaO}$ : The calcite content in phosphate rock is determined by the manganimetric method. Calcite increases the consumption of sulfuric acid for the attack [2]. A relatively pure acid can be produced from ore containing large quantities of calcite [2]. Calcite causes the formation of foam during the attack, especially nitric. This requires an increased amount of anti-foam, but they improve the reactivity of the ore, particularly appreciated in the production of phosphate fertilizers.

$\mathrm{P}_{2} \mathrm{O}_{5}$ : The strengths of orthophosphoric acid as well as analyses of phosphate rocks and fertilizers are usually expressed in terms of $\mathrm{P}_{2} \mathrm{O}_{5}$. The $\mathrm{P}_{2} \mathrm{O}_{5}$ content is determined by the gravimetric method and precipitation of $\mathrm{P}_{2} \mathrm{O}_{5}$ in a form of quinoline phosphomolybdate. Normally a preferred rock is the one that yields $\mathrm{P}_{2} \mathrm{O}_{5}$ as phosphoric acid at lowest cost, and primary consideration is usually the delivered price of the rock per unit of $\mathrm{P}_{2} \mathrm{O}_{5}$ [5]. The ratio of $\mathrm{CaO}$ to $\mathrm{P}_{2} \mathrm{O}_{5}$ eventually determines the amount of $\mathrm{H}_{2} \mathrm{SO}_{4}$ used per unit of $\mathrm{P}_{2} \mathrm{O}_{5}$ produced. Since the cost of of $\mathrm{H}_{2} \mathrm{SO}_{4}$ is a major factor in the production cost of phosphoric acid, a low $\mathrm{CaO}: \mathrm{P}_{2} \mathrm{O}_{5}$ ratio is preferred [5]. Many deposits have excess calcium, in compounds not associated with the phosphate that cannot be removed by beneficiation. The resulting high $\mathrm{CaO}_{2} \mathrm{P}_{2} \mathrm{O}_{5}$ ratio causes high $\mathrm{H}_{2} \mathrm{SO}_{4}$ consumption [5].

$\mathrm{CO}_{2}$ : The $\mathrm{CO}_{2}$ content is determined by a light hydrochloric attack and measuring the volume of gas released. Carbon dioxide appears with carbonates as important factors in the reactivity. They accentuate the formation of foam if the attack is produced in vacuo in a flash room (as reactor).

Organic matter $\left(\% \mathrm{C}_{\text {org }}\right)$ : The organic matter content is determined by titration of the organic matter oxidized by potassium dichromate. Organic matter increases the foam formation during the attack and thus increases the use of anti-foaming. They causes the formation of a trouble and a sank solid suspension into the produced acid. There are two types of organic matter present in the phosphate, the soluble and the insoluble organic matter. The soluble organic matter effect essentially on the produced phosphoric acid $26-28 \% \mathrm{P}_{2} \mathrm{O}_{5}$. And gives merchant phosphoric acid $54 \% \mathrm{P}_{2} \mathrm{O}_{5}$ black in color unwanted by polymers. Its use requires a preliminary clarification especially for the manufacture of technical acid. The insoluble organic matter, its effect is harmful to the filtration; in the tank of attack it inhibits of crystal growth phosphogypsum by changing the morphology of gypsum crystals, which affects the porosity and permeability of the gypsum cake on the filter. Also, the particles clog the pores of the gypsum layer, which do a screen and slowing the passage of liquid through the filter cloths. Therefore, the filtration efficiency is greatly affected.

$\mathrm{SO}_{4}$ : The sulphate content is determined by dosage of sulphate with a solution of barium chloride by the gravimetric method. Sulfates do not significantly alter the conditions of treatment unless they reach very high limits, and maintain the corresponding amount of sulfuric acid during the acidulation.

$\mathrm{CdO}$ : The cadmium content is determined by atomic absorption, the dosage of cadmium by photometric measurement of the absorption line in $228.8 \mathrm{~nm}$. Cadmium can be toxic in specific end products (animal food or fertilizers). It is in the form of traces in minerals. To be in global standards, the GCT must reduce the Cd content up to $10 \mathrm{ppm}$ and this is due to the use of a sulfide salt leads to precipitation of $\mathrm{Cd}$ and the separation of solid phase is done by filtration. This method generates an exhaust of $\mathrm{H}_{2} \mathrm{~S}$ and makes the atmosphere of the unit suffocating.

$\mathrm{Na}$ and $\mathrm{K}$ : The $\mathrm{Na}_{2} \mathrm{O}$ and $\mathrm{K}_{2} \mathrm{O}$ contents are determined by flame spectrophotometry. This method is applicable to inorganic phosphates which their contents in $\mathrm{Na}_{2} \mathrm{O}$ and $\mathrm{K}_{2} \mathrm{O}$ are respectively less than $2.7 \%$ and $0.24 \%$. $\mathrm{Na}$ and $\mathrm{K}$ react with fluorine and silica to form fluosilicates $\left(\mathrm{Na}_{2} \mathrm{SiF}_{6}\right.$ and $\left.\mathrm{K}_{2} \mathrm{SiF}_{6}\right)$ wich can produce muds in the equipment and whose elimination can raise important problems.

$\mathrm{Cl}$ : The chlorine content is determined by precipitation of chloride ions in the form of $\mathrm{AgCl}$. Chlorine is an undesirable impurity because of the danger of corrosion during the production of phosphoric acid and nitric attack. Usually it is dangerous from $0.1 \%$ only at high values because its corrosive action is influenced by interactions with other impurities.

Mg: The magnesium content is determined by atomic absorption, the dosage of magnesium by photometric measurement of the absorption line in $285.2 \mathrm{~nm}$. Magnesium in phosphoric acid has a double effect on the crystallization of gypsum. Combined with fluorine, it enhances crystallization, but over certain limit (2-3\%) it increases the viscosity of the acid which generates a rapid deterioration of the filtration rate.

$\mathrm{F}$ : The fluorine content is determined by metering volumetrically of fluorine in form of $\mathrm{H}_{2} \mathrm{SiF}_{6}$ with a solution of thorium nitrate. The fluorine causes problems of corrosion, mud, slurry formation and atmospheric pollution; moreover, it can decrease the filterability of gypsum due to the formation of complex salts. The fluorine can be a corrosive compound if the reactive silica is present in large quantities. With a high amount of sodium (1\% or more) the majority of fluorine will precipate during the reaction of attack. About half of the remaining part in the acid escapes during the concentration by evaporation [6]. 
$\mathrm{SiO}_{2}$ : The silica content is determined by the gravimetric method. The silica found in significant quantities leads to greater wear of the grinding apparatus and erodes the agitators and the pumps which handle slurries of attack. It can also negatively affect the filtration of gypsum in the production of phosphoric acid. A lack of silica below the stoichiometric amount necessary will involve the fluoride ion in form $\mathrm{SiF}_{6}$ and causes difficulties in the phosphoric acid purification for technical use so that the addition of active silica during the attack is necessary.

$\mathrm{Al}_{2} \mathrm{O}_{3}$ and $\mathrm{Fe}_{2} \mathrm{O}_{3}$ : The aluminum and iron contents are determined by atomic absorption, the dosage by photometric measurement of the absorption line in $309.3 \mathrm{~nm}$ for Al and $248,3 \mathrm{~nm}$ for Fe. In particular, alumina is undesirable because after dissolution of phosphate by the acid they form insoluble phosphates that decrease water soluble $\mathrm{P}_{2} \mathrm{O}_{5}$ content in product acid. In addition they reduce the filterability of gypsum. The highest commercial limit to be considered is equal to the ratio: $\frac{\mathrm{Al}_{2} \mathrm{O}_{3}+\mathrm{Fe}_{2} \mathrm{O}_{3}}{\mathrm{P}_{2} \mathrm{O}_{5}}=0.08$ to $0.1[2]$.

But the phosphates containing a mass content of aluminum less than 1.4 provide better filtration rate with an increasing amount of alumina [7]. Kruger and Fowles [8] showed that for low values of $\mathrm{Al}_{2} \mathrm{O}_{3}$, aluminum promotes the growth and consequently the formation of uniform crystals of gypsum thus improving the filtration rate, however, for high ratios of (aluminum / fluorine), it increases the viscosity of the acid and its density which has a detrimental effect on the filtration. By studying several sedimentary phosphates, Halaseh and Dukhggan [9] determined a ratio of fluorine complexation, $\mathrm{RCF}$, which is represented as follows:

$$
R C F=\frac{\frac{\% F}{19}}{\frac{\% \mathrm{Al}_{2} \mathrm{O}_{3}}{17}+\frac{\% \mathrm{SiO}_{2}}{15}}[9]
$$

Halaseh and Dukhggan [9] noticed that for the ratio $0.42 \leq \mathrm{RCF} \leq 1.378$, the filterability of phosphoric muds increases with the decrease of this ratio ( $R C F=0.571$ for raw phosphate 1 and $\mathrm{RCF}=0.868$ for raw phosphate 2 ), the mass content of the acid as $\mathrm{P}_{2} \mathrm{O}_{5}$ of acid increases and corrosion decreases, if this ratio is below 0.42 , the filterability decreases due to the presence of undissolved silica salts and a bad crystallization. By referring to RCF report and the filtration rate; phosphate 1 is more favorable to be studied kinetically [10].

\section{CONCLUSIONS}

From the chemical characterizations performed previously, we can affirm that the two qualities of phosphate can be used in the plants of phosphoric acid. However, phosphate 1 is more appreciated to be operated in the plants of phosphoric acid on the one hand and more favorable to be studied kinetically on the other hand.

\section{REFERENCES}

[1] Lehr, J. R. and McClellan, C. 1973. Phosphate Rocks: Important Factors in Their Economic and Technical Evaluation, CENTO, Symposium of the Mining and Beneficiation of Fertilizer Minerals. 1973. November 19-24. 142-194.

[2] Becker, P. 1983 Phosphate and Phosphoric Acid. Fertilizer Science and Technology Series. Marcel Decker. Vol.3. New York.

[3] Van der Sluis, S., Meszaros, Y., Wesselingh, J. A., and Van Rosmalen, G. M. 1986. A Clean Technology Phosphoric Acid Process. Proc. Fert. Soc. 1986 No. 249.

[4] Jaanikowsky, S. A. M., Robinson, N., and Sheldrick, W. 1964. Insoluble Phosphate Losses in Phosphoric Acid Manufacture by the Wet Process: Theory and Experimental Techniques. Presented at the 18th Meeting of the Fertilizer Society. London. 1964. Febr. 3-51.

[5] Slack, A. V. 1968. Phosphoric Acid. Fertilizer Science and Technology Series. Marcel Decker, New york, 1 (1968), 161.

[6] Frazier, A. W., Lehr, J. R., and Dillard, E. F. 1973. Chemical Behavior of Fluorine in the Production of Wet-Process Phosphoric Acid.

[7] Becker, P. 1983. Phosphate and Phosphoric Acid. Second edition. Revised and Expanded Fertiliser Science and Technology Series, Marcel Decker Inc, New York, Vol.3.

[8] Kruger, A., and Fowles, R. 1998. The effect of extraneous soluble ions in igneous rock phosphate on crystallography of gypsum dehydrate and thus phosphoric acid production, IFA technical conference, Marakesh. 1998. September.

[9] Halaseh, K., and Dukhggan, H. 1998. Operating experience of processing low grade Jordanian, Phosphates in the manufacture of WPA production, IFA Technical Conference Marakesh. 1998. September.

[10] CHAABOUNI, A., CHTARA, C., NZIHOU, A., and EL FEKI, H. 2013 Kinetic Study of the Dissolution of Tunisian Natural Phosphate or Francolite in Industrial Phosphoric Acid. J. Adv. in Chem. 6 (2013), 908-916. 